\title{
Comparative Study on the Treatment of Leachate from a Mine Waste Dump with Two Agricultural Biowastes
}

\section{Begoña Fernández Pérez, Julia Ayala Espina}

Escuela de Ingeniería de Minas, Energía y Materiales de Oviedo, C/Independencia 13, Oviedo Universidad de Oviedo, Oviedo, Spain Email: fernandezbegona@uniovi.es

How to cite this paper: Pérez, B. F., \& Espina, J. A. (2021). Comparative Study on the Treatment of Leachate from a Mine Waste Dump with Two Agricultural Biowastes. Journal of Geoscience and Environment Protection, 9, 52-63. https://doi.org/10.4236/gep.2021.99004

Received: August 16, 2021

Accepted: September 19, 2021

Published: September 22, 2021

Copyright (๑) 2021 by author(s) and Scientific Research Publishing Inc. This work is licensed under the Creative Commons Attribution International License (CC BY 4.0).

http://creativecommons.org/licenses/by/4.0/ (c) (i) Open Access

\begin{abstract}
Mining waste dumps are present all over the world. One of the main problems of these solid deposits is the migration of heavy metals present in them due to the aqueous solutions flowing through them. The comparison of the removal of heavy metals from an aqueous solution of a real mining waste leachate under different conditions by two different agricultural wastes has been investigated. The effect of $\mathrm{pH}$, contact time and dosage was studied using coffee grounds (CG) and walnut shells (WS), without pretreatment. The results obtained in the study showed the potential use of CG and WS for the removal of heavy metals, although the coffee grounds are the best adsorbents than the walnut shell.
\end{abstract}

\section{Keywords}

Adsorption, Mining Waste Leachate, Heavy Metals, Walnut Shells, Coffee Spent

\section{Introduction}

Some of the solid wastes produced during the mining and obtaining of metal concentrates may contain large amounts of hazardous substances, such as $\mathrm{Zn}$, $\mathrm{Cd}$ and $\mathrm{Ni}$, and are mostly dumped in the specific area (Owsianiak et al., 2015). Leachate from these deposits can be a major source of heavy metal contamination to soil, groundwater, or nearby effluents. The presence of these metals has a potentially harmful effect on ecosystems because some heavy metals are bio accumulative in living organisms and are non-biodegradable (Deng et al., 2019; Begum et al., 2019).

All conventional methods, such as adsorption method and electrochemical 
treatment, coagulation-flocculation, precipitation, liquid extraction, ion exchange, reverse osmosis, have been used at some point to remove or minimize heavy metal ion concentrations in industrial wastewater (Adamczuk \& Kołodyńska, 2015, Pujol et al., 2013, Wu et al., 2016). In recent years, research has also started to investigate the use of various agricultural wastes as low-cost adsorbents to remove heavy metals from solutions (Johnson et al., 2008; Ramos et al., 2016; Sladjana et al., 2019, Tharanga Bandara et al., 2020, Hizkeal Tsade et al., 2020).

Agriculture by-products are usually composed of lignin and cellulose as major constituents, comprising functional groups such as alcohols, aldehydes, carboxylic, phenolic and ether groups which are capable of binding to heavy. The formatter will need to create these components, incorporating the applicable criteria that follow.

The objective of this study is to compare two different low-cost and easily reusable agricultural wastes for their possible use in the treatment of heavy metal removal from mining waste leachates. The work presents the comparative results obtained during the last year, in the removal of several bivalent metals $\left(\mathrm{Zn}^{2+}\right.$, $\mathrm{Cd}^{2+}$ and $\mathrm{Ni}^{2+}$ ) obtained from real multicomponent solutions. The removal of heavy metal ions was studied under different conditions such as $\mathrm{pH}$, contact time and adsorbent doses.

\section{Materials and Methods}

\subsection{Materials}

Walnuts (Juglans regia) (WS) were collected from a local market and the shells were subsequently separated, washed, and dried at room temperature. They were then milled and placed in sealed polyethylene bottles for preservation.

The spent coffee grounds (CG) use, were collected from a coffee shop, dried in ambient air, and then placed in sealed polyethylene bottles for preservation.

All residues were characterized by means of different instrumental techniques: X-ray fluorescence (Phillips PW2404), X-ray diffraction analysis (Phillips X' PERT PRO) and FTIR spectral analysis (Varian 620-IR). The real density was determined using the pycnometer method (UNE Standard 80105), employing water as the immersion liquid Table 1.

All the chemical solutions used in this study were prepared using deionized water and analytical grade chemicals. Stock solutions were prepared containing $1000 \mathrm{mg} \cdot \mathrm{L}^{-1}$ of $\mathrm{Cd}, \mathrm{Ni}$, and $\mathrm{Zn}$, respectively. Solutions with the desired metal concentrations were prepared by successive dilutions of the stock solution.

The residual leachate was collected from an abandoned mine in northern Spain. For its characterization, $\mathrm{pH}$, redox potential, and electrical conductivity measurements were performed, using a PH2002 meter $\left(\right.$ Crison $\left.^{\circledR}\right)(\mathrm{pH}=5.18 ; 362$ $\mathrm{mV})$ and an EC-Meter Basic 30 device $\left(\right.$ Crison $\left.^{\circledR}\right),\left(518 \mu \mathrm{S} \cdot \mathrm{cm}^{-1}\right)$ respectively, and elemental analysis by inductively coupled plasma, mass spectrometry (ICP-MS, Agilent 7700) was performed (Table 2). 
Table 1. Chemical composition of the mineral matter of the walnut shells (WS) and spent coffee grounds (CG).

\begin{tabular}{cccccccccccc}
\hline Sample & $\begin{array}{c}\mathrm{K}_{2} \mathrm{O} \\
\text { \%wt }\end{array}$ & $\begin{array}{c}\mathrm{CaO} \\
\% \text { wt }\end{array}$ & $\begin{array}{c}\mathrm{SO}_{3} \\
\text { \%wt }\end{array}$ & $\begin{array}{c}\mathrm{MgO} \\
\text { \%wt }\end{array}$ & $\begin{array}{c}\mathrm{Na}_{2} \mathrm{O} \\
\text { \%wt }\end{array}$ & $\begin{array}{c}\mathrm{SiO}_{2} \\
\text { \%wt }\end{array}$ & $\begin{array}{c}\mathrm{Fe}_{2} \mathrm{O}_{3} \\
\% w t\end{array}$ & $\begin{array}{c}\mathrm{Al}_{2} \mathrm{O}_{3} \\
\text { \%wt }\end{array}$ & $\begin{array}{c}\mathrm{CuO} \\
\% w t\end{array}$ & $\begin{array}{c}\mathrm{P}_{2} \mathrm{O}_{5} \\
\% w t\end{array}$ & $\begin{array}{c}\mathrm{MnO} \\
\% w t\end{array}$ \\
\hline WS & 30.94 & 36.02 & 3.67 & 0.51 & 2.90 & 10.21 & 11.40 & 1.98 & 1.17 & 0.65 & 0.38 \\
CG & 40.51 & 21.20 & 19.2 & 3.11 & 4.92 & 2.22 & 1.34 & 0.76 & 0.70 & 4.81 & 0.71 \\
\hline
\end{tabular}

Table 2. Metal concentrations analyzed by ICP of mining waste leachate filtered.

\begin{tabular}{|c|c|c|c|}
\hline Major component & $\left(\mathrm{mg} \cdot \mathrm{L}^{-1}\right)$ & Minor component & $\left(\mu g \cdot L^{-1}\right)$ \\
\hline $\mathrm{Ni}$ & 18.1 & $\mathrm{Mn}$ & 24.25 \\
\hline $\mathrm{Zn}$ & 15.3 & $\mathrm{Cu}$ & 22.73 \\
\hline $\mathrm{Cd}$ & 68.19 & Co & 0.47 \\
\hline As & 5.8 & $\mathrm{Se}$ & 1.3 \\
\hline $\mathrm{Na}$ & 13.31 & $\mathrm{~V}$ & 0.77 \\
\hline $\mathrm{Mg}$ & 1.58 & $\mathrm{Ag}$ & 4.45 \\
\hline $\mathrm{K}$ & 19.38 & $\mathrm{~Pb}$ & 2.09 \\
\hline \multirow[t]{11}{*}{$\mathrm{Ca}$} & 35.98 & $\mathrm{Tl}$ & 0.04 \\
\hline & & $\mathrm{Sb}$ & 27.4 \\
\hline & & $\mathrm{B}$ & 20 \\
\hline & & $\mathrm{Al}$ & 460 \\
\hline & & $\mathrm{Ti}$ & 0.06 \\
\hline & & $\mathrm{Cr}$ & 11 \\
\hline & & Mo & 4.7 \\
\hline & & $\mathrm{Sr}$ & 167 \\
\hline & & $\mathrm{Sn}$ & 0.44 \\
\hline & & $\mathrm{Ba}$ & 4.9 \\
\hline & & $\mathrm{Fe}$ & 0.67 \\
\hline
\end{tabular}

\subsection{Batch Adsorption Experiments}

Different series of batch experiments were carried out to determine the influence of $\mathrm{pH}$, contact time, and adsorbent dosage.

These experiments were carried out by mechanically shaking series of $100 \mathrm{~mL}$ polyethylene bottles containing residue samples and metal solutions, employing an ad-sorbent concentration of $10 \mathrm{~g} \cdot \mathrm{L}^{-1}$, except in the tests performed to determine the influence of the amount of adsorbent.

Samples were shaken room temperature $\left(20^{\circ} \mathrm{C}\right)$ at $75 \mathrm{rpm}$, subsequently separating the two phases by filtration (Whatman 114 filter). The $\mathrm{pH}$ was measured and the concentrations of metal in the resulting supernatant were analyzed by atomic absorption spectroscopy.

For each metal solution, one sample was reserved for analysis to determine the initial metal concentration.

A series of experiments with synthetic solution were carried out to determine 
the influence of initial $\mathrm{pH}$ on the removal of metal ions, employing a $50 \mathrm{mg} \cdot \mathrm{L}^{-1}$ solution concentration. The initial $\mathrm{pH}$ of the solutions was adjusted from 2 to 7 using $\mathrm{H}_{2} \mathrm{SO}_{4}(0.01$ and $0.1 \mathrm{M})$ and $\mathrm{NaOH}(0.01$ and $0.1 \mathrm{M})$ solutions.

The dosage effect was studied by shaking solutions with different dosages of residues, ranging from 10 to $40 \mathrm{~g} \cdot \mathrm{L}^{-1}$. The amount of metal removed was determined by mass balances according to Equation (1):

$$
\text { Metal }_{\text {removed }}=\frac{\left(C_{o}-C_{e}\right)}{C_{o}} \times 100 \%
$$

The amount of metal ion removed (in milligrams per gram) by each residue was calculated according to Equation (2).

$$
q=\left(C_{o}-C_{e}\right) V / W_{s} \times 100 \%
$$

where $q$ is the amount of removed metal ion $\left(\mathrm{mg}^{-1} \mathrm{~g}^{-1}\right) ; W_{s}$, the amount of adsorbent $(\mathrm{g}) ; C_{o}$ and $C_{\mathrm{e}}$ the metal ion concentration $\left(\mathrm{mg} \cdot \mathrm{L}^{-1}\right)$ before and after removal, respectively; and $V$, the sample volume (L) (Farhadi et al., 2021).

\subsection{Adsorption Isotherms}

Different metal solutions were prepared with different concentrations $(2.5,5,10$, $20,20,40,50,50,60,100$ and $\left.150 \mathrm{mg} \cdot \mathrm{L}^{-1}\right)$ at $\mathrm{pH} 5$ and with an adsorbent concentration of $10 \mathrm{~g} \cdot \mathrm{L}^{-1}$ in each solution. The samples were left in agitation for $3 \mathrm{~h}$. They were then filtered and analyzed to determine the concentrations of metals present in solution.

The data obtained were fitted to Langmuir and Freundlich isotherms to describe the adsorption behavior of the metals obtained (Farhadi. et al., 2021).

The Langmuir adsorption isotherm is applied to equilibrium adsorption assuming monolayer adsorption on a surface with a finite number of identical sites. The Langmuir isotherm is represented by the following equation (3):

$$
\frac{C_{e}}{q_{e}}=\frac{1}{b a_{\max }}+\frac{C_{e}}{a_{\max }}
$$

where $C_{e}$ is the equilibrium concentration of the metal ion in solution $\left(\mathrm{mg} \cdot \mathrm{L}^{-1}\right) ; q_{e}$, the amount of metal adsorbed at equilibrium $\left(\mathrm{mg} \cdot \mathrm{g}^{-1}\right)$; while $b$ and $a_{\max }$ are Langmuir constants related to the binding constant and the maximum adsorption capacity, respectively. The values were estimated from the intercept and slope of the regression line for different initial metal concentrations.

The essential feature of the Langmuir isotherm can be expressed in terms of the dimensionless separation parameter, $R_{L}$, which is indicative of the isotherm shape that predicts whether an adsorption system is favorable or unfavorable. $R_{L}$ is defined as Equation (4):

$$
R_{L}=1 /\left(n\left(1+b C_{o}\right)\right)
$$

where $b$ is the Langmuir constant; and $C_{o}$ is the initial concentration. The $R_{L}$ value indicates the shape of the isotherm as follows: unfavorable $\left(R_{L}>1\right)$; linear; 
favorable $\left(0<R_{L}<1\right)$; or irreversible $\left(R_{L}=0\right)$ (Cheng et al., 2016, Imessaoudene et al., 2013).

The Freundlich model is applicable to sorption on heterogeneous surfaces with non-energetically equivalent sites. The adsorption data were also tested using the Freundlich isotherm equation:

$$
\log q_{e}=\log K+\frac{1}{n} \log C_{e}
$$

where $q_{e}$ is the amount of metal adsorbed at equilibrium $\left(\mathrm{mg}^{-1}\right)$; $C_{e}$, the equilibrium concentration of the metal ion in solution $\left(\mathrm{mg} \cdot \mathrm{L}^{-1}\right) ; K$, the equilibrium constant indicative of adsorption capacity; and $n$ is the adsorption equilibrium constant. If the value $1 / n$ is below unity, this implies that the sorption process is chemical; if the value is above unity, sorption is a favorable physical process.

The values of the adsorption parameters (Table 3 ) showed that the adsorption data obtained can fit both equations and represent favorable adsorption according to the coefficient of determination for the case of the heavy metals worked with. The values of $1 / n$ for the adsorption were found to be less than 0.5 , implying a chemical process.

\section{Results and Discussion}

\subsection{Characterization of the Adsorbent}

The mineral composition of the (WS) and (CG) was determined using an X-ray fluorescence (XRF). Table 1 shows that $\mathrm{Ca}$ and $\mathrm{K}$ are the most abundant mineral present in both wastes. $\mathrm{Al}, \mathrm{S}, \mathrm{Mn}$ and $\mathrm{Cu}$ were found at low concentrations $(<2 \% \mathrm{wt}$ ) and $\mathrm{Cr}, \mathrm{Ni}, \mathrm{Zn}, \mathrm{Ba}, \mathrm{Sr}$ and $\mathrm{Rb}$, as trace elements.

The mineral composition of the walnut shells and the spent coffee grounds depends on the type of cultivar, growth conditions, fertilizers used and soil properties as well as the variety grown.

The real density was determined using the pycnometer method. The values were $1.4 \mathrm{~g} \cdot \mathrm{cm}^{-3}$ and $1.318 \mathrm{~g} \cdot \mathrm{cm}^{-3}$ for (WS) and (CG), respectively.

Table 3. Langmuir and Freundlich adsorption isotherm constants (adsorbent concentration $=10 \mathrm{~g} \cdot \mathrm{L}^{-1}, \mathrm{t}=3 \mathrm{~h}, \mathrm{~T}=20^{\circ} \mathrm{C}, \mathrm{pH}=5$ ).

\begin{tabular}{|c|c|c|c|c|c|c|}
\hline \multirow[b]{2}{*}{ Metal } & \multicolumn{3}{|c|}{ Langmuir } & \multicolumn{3}{|c|}{ Freundlich } \\
\hline & $\begin{array}{c}a_{\max } \\
\left(\mathrm{mg} \cdot \mathrm{g}^{-1}\right)\end{array}$ & $\begin{array}{c}b \\
\left(\mathrm{~L} \cdot \mathrm{mg}^{-1}\right)\end{array}$ & $R^{2}$ & $K$ & $n$ & $R^{2}$ \\
\hline NiWS & 4.28 & 0.31 & 0.983 & 0.434 & 1.963 & 0.989 \\
\hline ZnWS & 4.29 & 0.41 & 0.992 & 0.494 & 1.982 & 0.969 \\
\hline Cd WS & 3.18 & 0.32 & 0.947 & 0.737 & 3.424 & 0.993 \\
\hline $\mathrm{Ni} \mathrm{CG}$ & 7.51 & 0.13 & 0.988 & 1.02 & 1.934 & 0.962 \\
\hline $\mathrm{Zn} \mathrm{CG}$ & 10.22 & 0.25 & 0.982 & 1.85 & 2.082 & 0.974 \\
\hline Cd CG & 5.96 & 0.28 & 0.994 & 1.35 & 2.643 & 0.98 \\
\hline
\end{tabular}




\subsubsection{X-Ray Diffractometry (XRD)}

$\mathrm{X}$-ray diffraction (XRD) analysis was carried out using an X-ray diffractometer (CuKa radiation). The diffractometer was operated at $45 \mathrm{kV}$ and $40 \mathrm{~mA}$, over the range of $2 \theta$ from $5^{\circ}$ to $80^{\circ}$, with a detector speed of $1^{\circ} \cdot \mathrm{min}^{-1}$. The XRD pattern reveals that walnut shells and spent coffee grounds are mainly amorphous and shows two peaks corresponding to the crystalline phase of cellulose (Abdolali et al., 2014, Ballesteros et al., 2014).

\subsubsection{FTIR Spectral Analysis}

FTIR spectra were obtained for solid samples before and after the adsorption process, Figure 1. Changes in band intensity and frequency after metal binding can be used to identify the functionalities involved in metal binding.

Many authors have reported the important role of carboxyl and hydroxyl groups in the biosorption process. The existence of active groups does not guarantee good removal of heavy metals, as adsorption depends on other factors such as how many active groups there are, where they are located, what charge they have under the working conditions, what affinity they have for a given metal, etc. (Nguyen et al., 2013).

Comparing the FTIR spectra of the samples before and after being put in contact with the leachate, it is observed that the peaks attributed to the $\mathrm{OH}$ and carboxyl groups have shifted to lower frequencies and their intensity has decreased. Therefore, it seems likely that these functional groups are involved in metal adsorption (Kante et al., 2012; Ramos et al., 2016; Vázquez et al., 2012).

\subsection{Characterization of the Leachate}

The physicochemical characteristics of the filtered wastewater were analyzed. Measurements were made of its $\mathrm{pH}=5.18$, redox potential $=362 \mathrm{mV}$ and electrical conductivity $=518 \mu \mathrm{S} \cdot \mathrm{cm}^{-1}$. Moreover, the concentrations of metals in the leachate were analyzed using the inductively coupled plasma (ICP) technique, Table 2. The leachate contained significant amounts of heavy metals such as $\mathrm{Cd}$, $\mathrm{Ni}, \mathrm{Zn}$ and $\mathrm{As}$, in addition to minor amounts of $\mathrm{Pb}, \mathrm{Cu}, \mathrm{Se}, \mathrm{Mn}, \mathrm{Cr}$ and $\mathrm{Mo}$.

\subsection{Batch Adsorption Experiments}

\subsubsection{Effect of $\mathrm{pH}$}

As can be seen in Figure 2, the metal ions uptake increased with increasing $\mathrm{pH}$. At pH 2, only $0.16 \mathrm{mg} / \mathrm{g}, 0.05 \mathrm{mg} / \mathrm{g}$ and $0.07 \mathrm{mg} / \mathrm{g}$ of $\mathrm{Zn}^{2+}, \mathrm{Cd}^{2+}$ and $\mathrm{Ni}^{2+}$ were respectively removed by (WS). In the metal ions uptake by the (CG), $\mathrm{Zn}$ is the metal that was adsorbed best, while the worst was $\mathrm{Cd}$ for both adsorbents.

On the other hand, the final $\mathrm{pH}$ of the solution after the removal of heavy metals was found to differ significantly from the initial $\mathrm{pH}$ Figure 3.

It is observed how the difference between the initial and final $\mathrm{pH}$ of the sample depends on the initial $\mathrm{pH}$. For very acidic solutions, the final $\mathrm{pH}$ is close to 2.3, whereas for the other solutions, the final $\mathrm{pH}$ is in the range of $5-6$ for treated and untreated samples. Srivastava et al. 2009 reported that the increase in solution $\mathrm{pH}$ during the sorption process appears to be the combined result of 
simultaneous and, perhaps, competitive adsorption of metal ions and $\mathrm{H}+$ ions on the adsorbents.

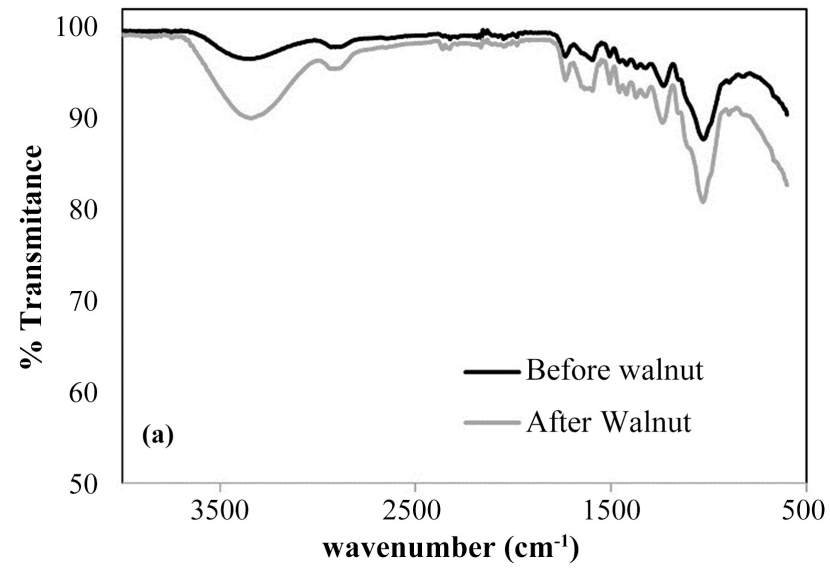

Figure 1. FTIR spectra of residues before and after being placed in contact with mining leachate. (a) CG before and after adsorption; (b) WS before and after adsorption.
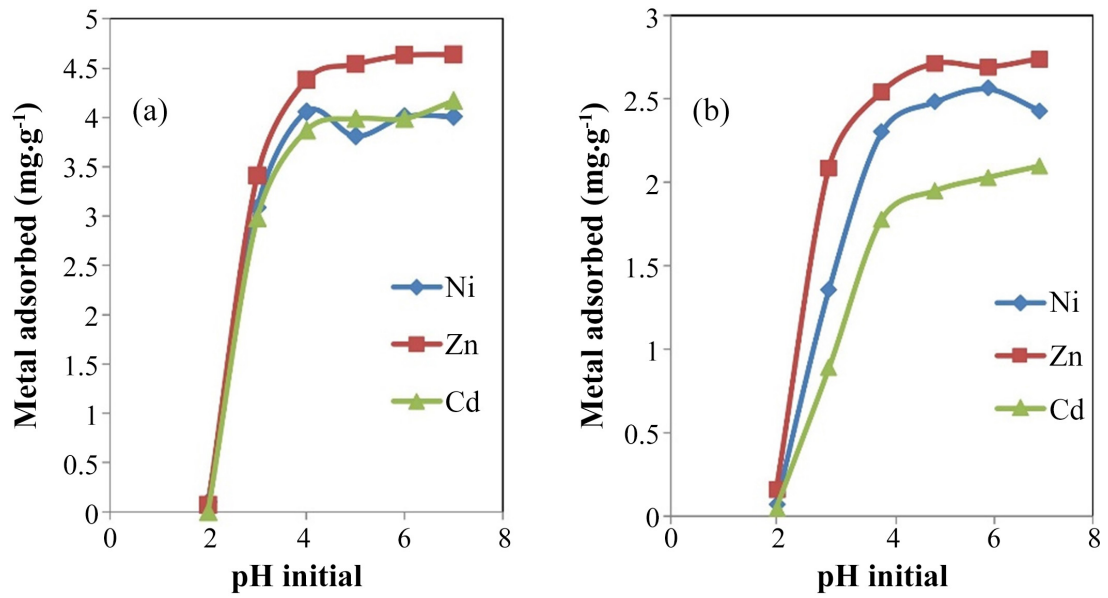

Figure 2. Metals adsorbed versus initial $\mathrm{pH}\left(C_{o}=50 \mathrm{mg} / \mathrm{L}\right.$, adsorbent concentration $=10$ $\mathrm{g} \cdot \mathrm{L}^{-1}, \mathrm{t}=3 \mathrm{~h}, \mathrm{~T}=20^{\circ} \mathrm{C}$ ). (a) CG; (b) WS.
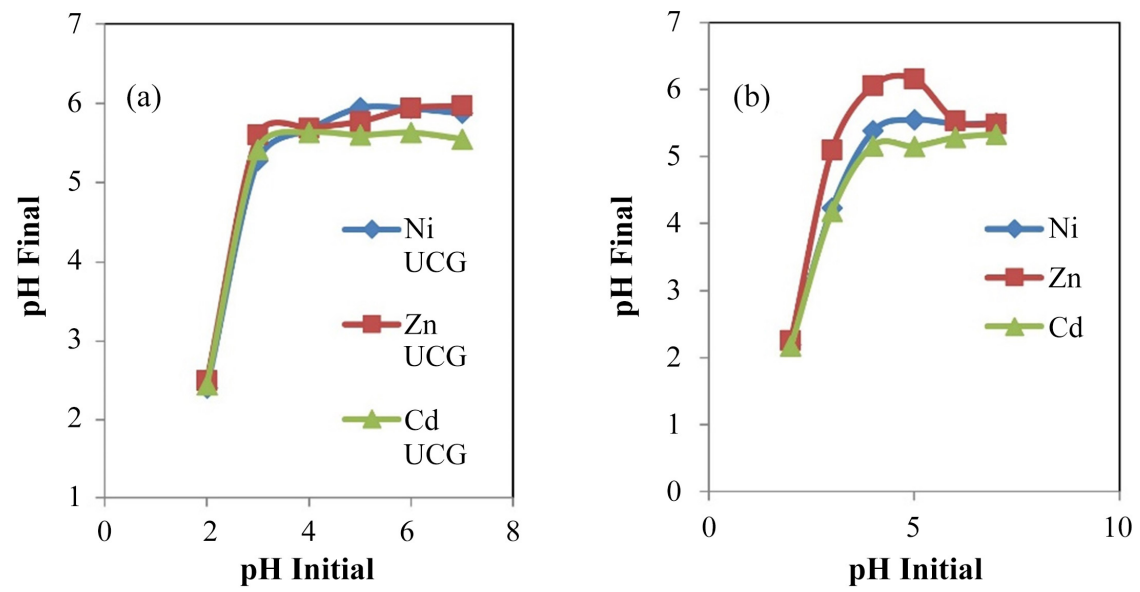

Figure 3. $\mathrm{pH}$ final versus initial $\mathrm{pH}\left(C_{o}=50 \mathrm{mg} \cdot \mathrm{L}^{-1}\right.$, adsorbent concentration $=10 \mathrm{~g} \cdot \mathrm{L}^{-1}, \mathrm{t}$ $=3 \mathrm{~h}, \mathrm{~T}=20^{\circ} \mathrm{C}$ ). (a) CG; (b) WS. 


\subsubsection{Treatment of Mining Waste Leachate}

The adsorption of heavy metals from leachate depends significantly on the number of contaminants and their relative concentrations. It also depends on the surface properties of the waste used and on the physicochemical parameters of the solution, such as $\mathrm{pH}$.

In particular, the presence of other ions in the leachate presents an inhibitory (antagonistic) sorption for $\mathrm{Ni}$ and $\mathrm{Zn}$, which results in a lower sorption yield. However, it exerts a synergistic effect in the case of $\mathrm{Cd}$, increasing its removal. Srivastava et al. 2009 studied this result for $\mathrm{Ni}$ and $\mathrm{Zn}$ in the case of rice husk ash and reported similar results. These authors suggest that there is a variety of adsorption binding sites on the surface of the adsorbent that exhibit a partially specific affinity for individual metal.

Table 3 shows the number of cations (meq.g $\mathrm{g}^{-1}$ ) that had passed into solution after the treatment of the leachate using (CG) and (WS) and the amount of heavy metals removed. The data show that there is ion exchange between heavy metals and alkali and alkaline earth ions.

The ratio of metal removed to cation released $\left(\mathrm{Rb} \cdot \mathrm{r}^{-1}\right)$ is $<1$; therefore, there were more $\mathrm{Na}^{+}, \mathrm{K}^{+}, \mathrm{Ca}^{2+}$ and $\mathrm{Mg}^{2+}$ ions passed into solution than adsorbed metals. This is because water can also exchange $\mathrm{H}^{+}$with these metals present in the residues. This leads to a decrease in these ions, which in turn leads to an increase in the $\mathrm{pH}$ of the leachate after treatment.

This mechanism of ionic change has been suggested by other authors in the literature in combination with some other types of interactions such as physical force and/or chelation in the biosorption of metals. As can be seen in Figure 4, the final concentration of $\mathrm{Zn}, \mathrm{Cd}$ and $\mathrm{Ni}$ can be reduced by increasing the adsorbent dose.

To confirm the ionic mechanisms, the amount of $\mathrm{Na}^{+}, \mathrm{K}^{+}, \mathrm{Ca}^{2+}$ and $\mathrm{Mg}^{2+}$ released due to the sorption process was calculated by subtracting the amount of these metals in the supernatant and the amount of these metals present in the leachate.

Table 4 shows the number of cations (meq. $\mathrm{g}^{-1}$ ) that had passed into solution after treatment of the leachate with WS and CG using a concentration of $10 \mathrm{~g} \cdot \mathrm{L}^{-1}$ of adsorbent, as well as the amount of $\mathrm{Zn}^{2+}, \mathrm{Cd}^{2+}, \mathrm{Ni}^{2+}$ and $\mathrm{Al}^{3+}$ removed.

\subsubsection{Effect of Contact Time}

The influence of contact time on metal ions uptake in real wastewater can be shown in Figure 5.

Table 4. Released cations due the adsorption of $\mathrm{Zn}^{2+}, \mathrm{Cd}^{2+}$ and $\mathrm{Ni}^{2+}$ onto (a) WS and (b) CG.

\begin{tabular}{ccccccccc}
\hline \multicolumn{3}{c}{ Total metal bound (meq.g $\left.{ }^{-1}\right)$} & \multicolumn{5}{c}{ Amount of cation released (meq.g ${ }^{-1}$ ) } \\
\hline $\mathrm{Zn}^{2+}$ & $\mathrm{Cd}^{2+}$ & $\mathrm{Ni}^{2+}$ & $\mathrm{Al}^{3+}$ & $\mathrm{Na}^{+}$ & $\mathrm{K}^{+}$ & $\mathrm{Ca}^{2+}$ & $\mathrm{Mg}^{2+}$ & $\mathrm{Rb} / \mathrm{r}$ \\
\hline a 0.0153 & 0.0589 & 0.0158 & 0.0050 & 0.0103 & 0.0675 & 0.0359 & 0.0277 & 0.671 \\
b 0.0354 & 0.0972 & 0.0337 & 0.0050 & 0.0217 & 0.1838 & & 0.1165 & 0.532 \\
\hline
\end{tabular}

$\mathrm{Rb} \cdot \mathrm{r}^{-1}$ : Ratio of metal bound to cation released. 

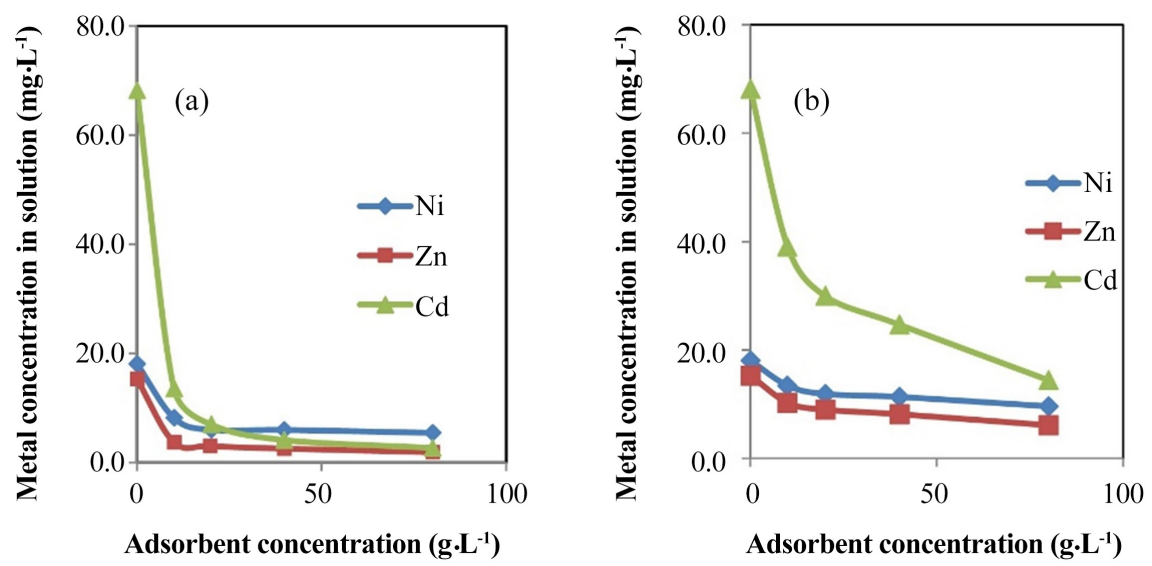

Figure 4. Effect of the amount of metal in solution versus adsorbent concentration $\left(\mathrm{g} \cdot \mathrm{L}^{-1}\right)$ time $=3 \mathrm{~h}, \mathrm{~T}=20^{\circ} \mathrm{C}, 75 \mathrm{rpm}$ : (a) CG; (b) WS.
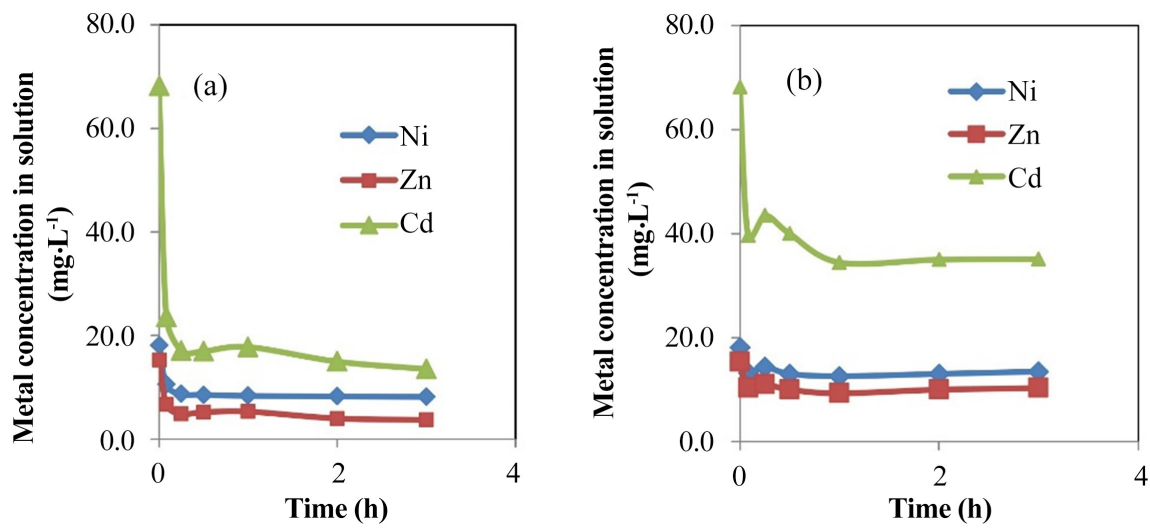

Figure 5. The influence of contact time on metal ions uptake, absorbent concentration 10 $\mathrm{g} \cdot \mathrm{L}^{-1}, \mathrm{~T}=20^{\circ} \mathrm{C}, 75 \mathrm{rpm}$ : (a) CG; (b) WS.

Experiments showed that the adsorption of metal ions on (WS) and (CG) is a two-step process. Eliminations of more than $75 \%$ of the metal ions were obtained in the first $5 \mathrm{~min}$, reaching the maximum adsorption after $3 \mathrm{~h}$. In the test performed with (WS), an equilibrium value of $48.7 \%, 32.8 \%$ and $25.4 \%$ was achieved for $\mathrm{Cd}, \mathrm{Zn}$ and $\mathrm{Ni}$, respectively, and for (CG) of $80.2 \%, 87.5 \%$ and $54 \%$ for $\mathrm{Cd}, \mathrm{Zn}$ and $\mathrm{Ni}$, respectively.

It is also observed that no adsorption occurs above the equilibrium concentration when the samples are stirred for 24 hours. The same effect has been reported by other authors (Abdolali et al., 2014). Therefore, $3 \mathrm{~h}$ were chosen for equilibrium studies to ensure that adsorption reached equilibrium.

These results can be explained by the fact that the surface-active sites of the residues were initially empty, and the heavy metal concentration was high. After 5 min of contact, many of the functional groups, responsible for the adsorption process, are already bound to the metal ions and therefore the adsorption rate decreases. This means that the metal ions must be transported from the outside to the inner sites of the adsorbent particles. Generally, when adsorption involves a surface reaction process, the initial adsorption is rapid, progressively decreas- 
ing as the active sites decrease.

\subsubsection{Effect of Dosage}

Figure 4 shows how the amount of adsorbed metal $\left(\mathrm{mg} \cdot \mathrm{g}^{-1}\right)$ decreases progressively with increasing adsorbent concentration. The explanation for this is that metal adsorption is subject to the "particle concentration effect" because of flocculation of the solid phase, with a consequent decrease in the available surface area (Ayala \& Fernandez 2016; Petrovič \& Simonič, 2016; Karimi-Jashni \& Saadat, 2014).

\section{Conclusion}

The objective of this study is focused on the comparison of the behavior versus their adsorption capacity of heavy metals in a real leachate from an abandoned mine dump, of two different agricultural wastes. The results obtained show that both untreated wastes, walnut shells (WS) and coffee grounds (CG), can be used as adsorbents for the removal of $\mathrm{Zn}^{2+}, \mathrm{Ni}^{2+}$ and $\mathrm{Cd}^{2+}$ from real wastewater.

The adsorption of metals is very fast and highly dependent on $\mathrm{pH}$, with maximum removal occurring at $\mathrm{pH}>5$. The concentration of heavy metals can be reduced by increasing the adsorbent dosage, with the metal removal request being $\mathrm{Cd}>\mathrm{Zn}>\mathrm{Ni}$, for both adsorbents.

On the other hand, the presence of other cations in the solution significantly reduced the adsorption of metals. Divalent ions present a more negative effect than monovalent ions on both residues.

Finally, and in view of the differences for both wastes, it can be concluded that coffee grounds are better adsorbents than walnut shells, although what has been demonstrated is that both could become an effective alternative for a viable circular economy treatment.

\section{Acknowledgements}

This research did not receive any specific grant from funding agencies in the public, commercial, or not-for-profit sectors.

\section{Conflicts of Interest}

The authors declare no conflicts of interest regarding the publication of this paper.

\section{References}

Abdolali, A., Guo, W. S., Ngo, H. H., Chen, S. S., Nguyen, N. C., \& Tung, K. L. (2014). Typical Lignocellulosic Wastes and By-Products for Biosorption Process in Water and Wastewater Treatment: A Critical Review. Bioresource Technology, 160, 57-66. https://doi.org/10.1016/j.biortech.2013.12.037

Adamczuk, A., \& Kołodyńska (2015). Equilibrium, Thermodynamic and Kinetic Studies on Removal of Chromium, Copper, Zinc and Arsenic from Aqueous Solutions onto Fly Ash Coated by Chitosan. Chemical Engineering Journal, 274, 200-212. 
https://doi.org/10.1016/j.cej.2015.03.088

Ayala, J., \& Fernandez, B. (2016). A Case Study of Landfill Leachate Using Coal Bottom Ash for the Removal of $\mathrm{Cd}^{2+}, \mathrm{Zn}^{2+}$ and $\mathrm{Ni}^{2+}$. Metals, 6, 300 .

https://doi.org/10.3390/met6120300

Ballesteros, L. F., Teixeira, J. A., \& Mussatto, S. I. (2014). Chemical, Functional, and Structural Properties of Spent Coffee Grounds and Coffee Silver Skin. Food and Bioprocess Technology, 7, 3493-3503. https://doi.org/10.1007/s11947-014-1349-Z

Bandara, T., Xu, J. M., Potter, I. D., Franks, A. F., Chathurika, J. B. A. J., \& Tang, C. X. (2020). Mechanisms for the Removal of Cd(II) and $\mathrm{Cu}(\mathrm{II})$ from Aqueous Solution and Mine Water by Biochars Derived from Agricultural Wastes. Chemosphere, 254, Article ID: 126745. https://doi.org/10.1016/j.chemosphere.2020.126745

Begum, B. A., Devanna, N., \& Chari, M. A. (2019). Low-Cost Adsorbents Procedure by Means of Heavy Metal Elimination from Wastewater. https://doi.org/10.20944/preprints201902.0013.v1

Cheng, L., Xue, W., \& Zeng, Z. (2016). Removal of Pb(II) from Aqueous Solution by Acrylic Acid Modified Walnut Shell: Isotherms and Kinetics. American Chemical Science Journal, 112, 1-9. https://doi.org/10.9734/ACSJ/2016/23548

Deng, Y. Y., Huang, S., Laird, D. A., Wang, X. G., \& Meng, Z. W. (2019). Adsorption Behaviour and Mechanisms of Cadmium and Nickel on Rice Straw Biochars in Singleand Binary-Metal Systems. Chemosphere, 218, 308-318. https://doi.org/10.1016/j.chemosphere.2018.11.081

Farhadi, A., Ameri, A., \& Tamjidi, S. (2021). Application of Agricultural Wastes as a Low-Cost Adsorbent for Removal of Heavy Metals and Dyes from Wastewater: A Review Study. Physical Chemistry Research, 9, 211-226.

Imessaoudene, D., Hanini, S., \& Bouzidi, A. (2013). Biosorption of Strontium from Aqueous Solutions onto Spent Coffee Grounds. Journal of Radioanalytical and Nuclear Chemistry, 298, 893-902. https://doi.org/10.1007/s10967-013-2510-2

Johnson, T. A., Jain, N., Joshi, H. C., \& Prasad, S. (2008). Agricultural and Agro-Processing Wastes as Low Cost Adsorbents for Metal Removal from Wastewater: A Review. Journal of Scientific \& Industrial Research, 67, 647-658.

Kante, K., Nieto-Delgado, C., Rangel-Mendez, J. R., \& Bandosz, T. J. (2012). Spent Coffee-Based Activated Carbon: Specific Surface Features and Their Importance for H2S Separation Process. Journal of Hazardous Materials, 201-202, 141-147. https://doi.org/10.1016/j.jhazmat.2011.11.053

Karimi-jashni, A., \& Saadat, S. (2014). Investigation of Factors Affecting Removal of Nickel by Pre-Treated Walnut Shells Using Factorial Design and Univariate Studies. Transactions of Civil Engineering, 38, 309-324.

Nguyen, T. A. H., Ngo, H. H., Guo, W. S., Zhang, J., Liang, S., Yue, Q. Y., Li, Q., \& Nguyen, T. V. (2013). Applicability of Agricultural Waste and By-Products for Adsorptive Removal of Heavy Metals from Wastewater. Bioresource Technology, 148, 574-585. https://doi.org/10.1016/j.biortech.2013.08.124

Owsianiak, M., Holm, P. E., Fantke, P., Christiansen, K. S. Borggaard, O. K., \& Hauschild, M. Z. (2015). Assessing Comparative Terrestrial Ecotoxicity of $\mathrm{Cd}, \mathrm{Co}, \mathrm{Cu}, \mathrm{Ni}, \mathrm{Pb}$, and $\mathrm{Zn}$ : The Influence of Aging and Emission Source. Environmental Pollution, 206, 400-410. https://doi.org/10.1016/j.envpol.2015.07.025

Petrovič, A., \& Simonič, M. (2016). Removal of Heavy Metal Ions from Drinking Water by Alginate-Immobilised Chlorella sorokiniana. International Journal of Environmental Science and Technology, 13, 1761-1780. https://doi.org/10.1007/s13762-016-1015-2

Pujol, D., Bartrolí, M., Fiol, N., de la Torre, F., Villaescusa, I., \& Poch, J. (2013). Model- 
ling Synergistic Sorption of $\mathrm{Cr}(\mathrm{VI}), \mathrm{Cu}(\mathrm{II})$ and $\mathrm{Ni}(\mathrm{II})$ onto Exhausted Coffee Wastes from Binary Mixtures $\mathrm{Cr}(\mathrm{VI})-\mathrm{Cu}(\mathrm{II})$ and $\mathrm{Cr}(\mathrm{VI})-\mathrm{Ni}(\mathrm{II})$. Chemical Engineering Journal, 230, 396-405. https://doi.org/10.1016/j.cej.2013.06.033

Ramos, S. N. C., Xavier, A. L. P., Teodoro, F. S., Gil, L. F., \& Gurgel, L. V. A. (2016). Removal of Cobalt(II), Copper(II), and Nickel(II) Ions from Aqueous Solutions Using Phthalate-Functionalized Sugarcane Bagasse: Mono- and Multicomponent Adsorption in Batch Mode. Industrial Crops and Products, 79, 116-130.

https://doi.org/10.1016/j.indcrop.2015.10.035

Sladjana, M. et al. (2019). Utilization of Agro-Industrial Waste for Removal of Copper Ions from Aqueous Solutions and Mining-Wastewater. Journal of Industrial and Engineering Chemistry, 75, 246-252. https://doi.org/10.1016/j.jiec.2019.03.031

Srivastava, V. C., Mall, I. D., \& Mishra, I. M. (2009). Equilibrium Modeling of Ternary Adsorption of Metal Ions onto Rice Husk Ash. Journal of Chemical \& Engineering Data, 54, 705-711. https://doi.org/10.1021/je8003029

Tsade, H., Murthy, H. C. A., \& Muniswamy, D. (2020). Bio-Sorbents from Agricultural Wastes for Eradication of Heavy Metals: A Review. Journal of Materials and Environmental Science, 11, 1719-1735.

Vázquez, G., Mosquera, O., Freire, M. S., Antorrena, G., \& González-Álvarez, J. (2012). Alkaline Pre-Treatment of Waste Chestnut Shell from a Food Industry to Enhance Cadmium, Copper, Lead and Zinc Ions Removal. Chemical Engineering Journal, 184, 147-155. https://doi.org/10.1016/j.cej.2012.01.019

Wu, C.-H., Kuo, C.-Y., \& Guan, S.-S. (2016). Adsorption of Heavy Metals from Aqueous Solutions by Waste Coffee Residues: Kinetics, Equilibrium, and Thermodynamics. Desalination and Water Treatment, 57, 5056-5064. https://doi.org/10.1080/19443994.2014.1002009 